\title{
Influence of Local Sand on the Physicomechanical Comportment and Durability of High Performance Concrete
}

\author{
Nadia Tebbal $^{\mathbf{1}}$ and Zine El Abidine Rahmouni ${ }^{2}$ \\ ${ }^{1}$ Institute of Urban Management Techniques, University of M'sila, M'Sila, Algeria \\ ${ }^{2}$ Department of Civil Engineering, University of M'sila, M'Sila, Algeria \\ Correspondence should be addressed to Zine El Abidine Rahmouni; rahmouniz@yahoo.fr
}

Received 23 March 2016; Revised 17 September 2016; Accepted 10 October 2016

Academic Editor: Luigi Di Sarno

Copyright (c) 2016 N. Tebbal and Z. E. A. Rahmouni. This is an open access article distributed under the Creative Commons Attribution License, which permits unrestricted use, distribution, and reproduction in any medium, provided the original work is properly cited.

\begin{abstract}
This research consists of incorporating the crushed sand (CS) in the composition of a concrete and studies the effect of its gradual replacement by the sand dune (SD) on sustainability of high performance concrete (HPC) in aggressive environments. The experimental study shows that the parameters of workability of HPC are improved when the CS is partially replaced by the SD $(<2 / 3)$. However, a high content of SD $(>1 / 3)$ additional quantities of water is needed to meet the workability properties. The mechanical strengths decrease by adding the SD to CS, but they reach acceptable values with CS in moderate dosages. The HPC performances are significantly better than the control concrete made up with the same aggregates. The specification tests of durability show that the water absorbing coefficients by capillarity increase after adding SD to the CS.
\end{abstract}

\section{Introduction}

Current trends in the formulation of high performance concrete and low environmental impact show that the solid volume fraction is increasingly high. However, increasing the volume fraction of solid presents serious effects on the workability of new concrete. The high performance concrete (HPC) is highly fluid concrete which requires high dosages of sand and fine elements compared to ordinary concrete (OC). The crushed sand (CS), with wide granularity, is a byproduct of crushing massive rocks. Sand dune (SD) is extrafine sand, characterized by a tight size distribution of the grains. Containing high content of fines, these types of sand can be interesting components of HPC $[1,2]$.

For a good concrete mix, fine aggregates need to be clean, hard, strong, and free of absorbed chemicals and other fine materials that could cause the deterioration of concrete. Unfortunately, majority of the natural sand used (rolled sand: sand of river, dune sand, and sand of sea) is selected for the price and the availability $[3,4]$. Properties of sand affect the durability and performance of mortar, as fine aggregate is an essential component of concrete.
Many researches showed that manufactured sand is a best alternative for natural sand in terms of strength and durability and the concrete mix with $60 \%$ replacement has given good durable properties [5].

Hudson, 1997, conducted a study using natural and crushed sand to compare the resistance and characteristics of concrete with high fine material [6]. Ahmad and Mahmood 2008 investigated the effects of crushed and natural sand on the properties of fresh and hardened concrete. The workability of concrete manufactured with crushed sand was lesser than that manufactured with natural sand. This reduction was from $6 \%$ to $11 \%$ [7].

Ilangovan et al., 2006, studied the strength and behavior of concrete using crushed rock dust as fine aggregate; they investigated the possibility of using crushed rock as $100 \%$ replacement for sand, with varying compacting factors [8]. Baali et al., 2007, have studied the substitution of the dune sand by the ground sand (calcined clay) influences appreciably on the water demand necessary to have acceptable workability (fluidity or consistency) of fresh mortar [9]. Narasimha et al., 1999, investigated experimentally the performance of concrete with quarry dust as fine aggregate [10]. Sahu et al., 
2003, investigated the crushed stone waste as fine aggregate for concrete [11].

Makhloufi et al., 2014, studied the effect of the sand type on the main properties of sand concrete: fracture and mechanical properties. Four different types of sand have been used: dune sand (DS), river sand (RS), crushed sand (CS), and river-dune sand (RDS). These types of sand differ in mineralogical nature, grain shape, angularity, particle size, proportion of fine elements, and so forth. The obtained results show that the particle size distribution of sand has marked its influence in all the studied properties of sand concrete since the sand having the highest diameter and the best particle size distribution has given the best fracture and mechanical properties. The grain shape, the angularity, and the nature of sand have also marked their influence: thanks to its angularity and its limestone nature, crushed sand yielded good results compared to river and dune sand which are characterized by rounded shape and siliceous nature [12].

The study on the properties of concrete by replacement of natural sand with artificial sand was conducted by Vinayak, 2012. The results have shown that the natural sand can be replaced with the artificial sand up to a maximum replacement level of $60 \%$ in order to produce concrete of satisfactory workability and compressive strength. The results have also indicated that concrete slab panels showed minimum area of cracks on their surfaces, thus improving the durability property [13].

Priyanka 2013, the research confirmed that the compressive strength of cement mortar with 50\% replacement of natural sand by manufactured sand reveals a higher strength as compared to reference mix. The overall strength of mortar linearly increases for $0 \%$ and $50 \%$ replacement of natural sand by manufactured sand as compared with reference mix. The effect of partial replacement of natural sand by manufactured sand on the compressive strength of cement mortar of proportion $1 / 2,1 / 3$, and $1 / 6$ with water cement ration as 0.5 and 0.55 is studied. Results are compared with reference mix of $0 \%$ replacement of natural sand by manufactured sand [14].

The experimental study shows that the workability parameters of HPC improve when the CS is partially replaced by the SD $(<60 \%)$. However, with a high content of SD (>30\%), additional quantities of water are required to meet the properties of workability. By adding SD to the CS, the mechanical strength decreases but reaches acceptable values with CS in moderate dosages. The HPC performances are significantly better than those of control concrete made with the same aggregates. The specifications tests of the durability show that coefficients of water absorption increased capillarity by adding SD to CS [15].

The term "durability" has been described as the ability to resist against environmental risks and maintaining desired engineering properties [16]. Sulfates present in sea water, groundwater, and soils influence a surrounding concrete structure and cause a major risk to the long term durability of the exposed elements to these hazardous environments. Sulfate attack of concrete might lead to cracking, spalling, increased permeability, and strength loss. As a consequence, resistance of concrete to sulfate attack is of great importance to ensure satisfactory performance of the concrete structure in long term period [17].

Sulfates are salts of sulfuric acid $\left(\mathrm{H}_{2} \mathrm{SO}_{4}\right)$, such as sodium sulfate (mirabilite $\mathrm{Na}_{2} \mathrm{SO}_{4} \cdot 10 \mathrm{H}_{2} \mathrm{O}$ ); calcium sulfate (gypsum and anhydrite $\mathrm{CaSO}_{4} \mathrm{CaSO}_{4} \cdot 2 \mathrm{H}_{2} \mathrm{O}$ ); and magnesium sulfate (kieserite $\mathrm{MgSO}_{4} \cdot \mathrm{H}_{2} \mathrm{O}$ and epsomite $\mathrm{MgSO}_{4} \cdot 7 \mathrm{H}_{2} \mathrm{O}$ ) [18]. These sulfates from soil, groundwater, wastewater, seawater, acid rain are linked to air pollution industrial and radioactive waste [19]. HPC require, among other things, high levels of sand and fillers as compared to conventional concrete. This study shows the importance of this method to make concrete with binary sand (natural and manufactured fine aggregates) in order to correct the physical properties of sand. Using a mixture of dune and crushed sand in various proportions allows obtaining high strength concrete.

The sulfate attack can significantly deteriorate the concrete in a relatively short period (10-15 years), by two physicochemical mechanisms, namely, the loss of binding properties of hydrates of silicates and expansion [20]. Impaired binding properties of hydrates leads to a loss of mechanical strength and mass. Also, aluminates and portlandite are the most vulnerable to the expansion that generates considerable damage. However, concrete deterioration is caused by the secondary ettringite formation and secondary gypsum, pressure, and consequent cracking [21].

In Algeria with its geological diversity, there is real wealth in terms of construction materials (gravel and sand). The solid rock quarries produce considerable amounts of crushed sand (CS) which discarded the composition of concrete. In addition, the south contains endless amounts of sand dune (SD), which has never been seriously exploited in the construction's field. However, these types of sand (CS and SD) naturally contain high levels of fines that can be an interesting source for composition of high performance concrete (HPC). They can increase productivity and reduce delay of realization on site. They provide substantial gains weight; it is possible to construct with less formwork, less concrete to implement, and less of reinforcing steel than with ordinary concrete. This has been shown for the HPC (gains of 25-40\%) [18-22].

This research aims to study the effect of using crushed sand as partial replacement of dune sand in various percentages $(0,1 / 3,2 / 3$, and $100 \%)$ on the physicomechanical properties of HPC made with binary natural fine aggregates (SD and CS) at aggressive environment. Different types of concrete HPC are made of using materials and products manufactured in Algeria: Portland Artificial CPJ CEM II 42.5 cement, superplasticizer (SP), two fractions of gravel (3/8) and $(8 / 15) \mathrm{mm}$, and two fillers (silica fume, granulated slag) with two types of sand CS (0/5) and SD (0/5) mm.

\section{Material and Experimental Method}

Cement, Portland cement (CEM II 42.5), has a Blaine specific surface area of $385 \mathrm{~cm}^{2} / \mathrm{g}$ and a density of 3.2 . Chemical and mineralogical composition is given by Bogue's formulas (Table 1).

The aggregates which served in the composition of the concrete in this study consist of crushed limestone sand (CS) and siliceous sand dune (SD) $\left(\mathrm{SiO}_{2}=86.95 \%\right)$. Two gravels 
TABLE 1: Chemical and mineralogical composition of cement, granulated slag, and silica fume.

\begin{tabular}{|c|c|c|c|c|}
\hline & Compositions (\%) & Cement & Slag & Silica fume \\
\hline \multirow{10}{*}{ Chemical compositions } & $\mathrm{SiO}_{2}$ & 18.48 & 41.69 & $>80$ \\
\hline & $\mathrm{CaO}$ & 61.04 & 39.77 & \\
\hline & $\mathrm{Al}_{2} \mathrm{O}_{3}$ & 4.51 & 7.05 & \\
\hline & $\mathrm{Fe}_{2} \mathrm{O}_{3}$ & 3.21 & 1.41 & \\
\hline & $\mathrm{MgO}$ & 2.16 & 5.49 & \\
\hline & $\mathrm{SO}_{3}$ & 2.18 & 0.15 & $<2.5$ \\
\hline & $\mathrm{MnO}$ & - & - & \\
\hline & $\mathrm{Na}_{2} \mathrm{O}$ & 0.13 & 0.10 & \\
\hline & $\mathrm{K}_{2} \mathrm{O}$ & 0.56 & 0.44 & \\
\hline & $\mathrm{Cl}^{-}$ & & & $<0.2$ \\
\hline \multirow{5}{*}{ Mineralogical compositions } & $\mathrm{C}_{3} \mathrm{~S}$ & 57 & & \\
\hline & $\mathrm{C}_{2} \mathrm{~S}$ & 18 & & \\
\hline & $\mathrm{C}_{3} \mathrm{~A}$ & 07 & & \\
\hline & $\mathrm{C}_{4} \mathrm{AF}$ & 11 & & \\
\hline & Gypse & 15 & & \\
\hline
\end{tabular}

(G) crushed limestone (3/8) and (8/15) $\mathrm{mm}$ from the same quarry as the crushed sand.

(i) Dune Sable. The sand used was dune sand with particles ranging from $0.08 \mathrm{~mm}$ to $5 \mathrm{~mm}$ in size. The natural sand was takedn from Boussâada, Algeria. The granulometric study is performed according to the European standard NF EN 9331 [23] after the treatment process allows us to eliminate a significant portion of clay minerals.

The mineralogical composition determined by $\mathrm{X}$-ray diffraction shows that the siliceous sand dune is more than $95 \%$ of quartz and calcite traces. The results are shown in Figure 1.

(ii) Crushed Fine Aggregate. In this study the manufactured fine aggregate used crushed sand generated by the quarry waste. The effect of quarry waste replacement by normal weight dune sand $(0,1 / 3,2 / 3 \%$, and 100 by volume) was investigated. Chemical composition of fine aggregates (Table 2). According to the results obtained concerning the physical properties of natural and artificial sand (Table 3), we have the following:

(i) SD has a low compactness compared to the crushed sand; this is primarily with its fine particles (low fineness modulus).

(ii) CS has a less high porosity and water absorption compared to the dune sand; this may be attributed to its ordinary particles (coarse fineness modulus).

Based on the analysis of the results particle size distribution and fineness modulus, the sand used in the study can be categorized as follows:

(i) The dune sand presents a fine particle size distribution.

(ii) The crushed sand presents a coarse particle size distribution.

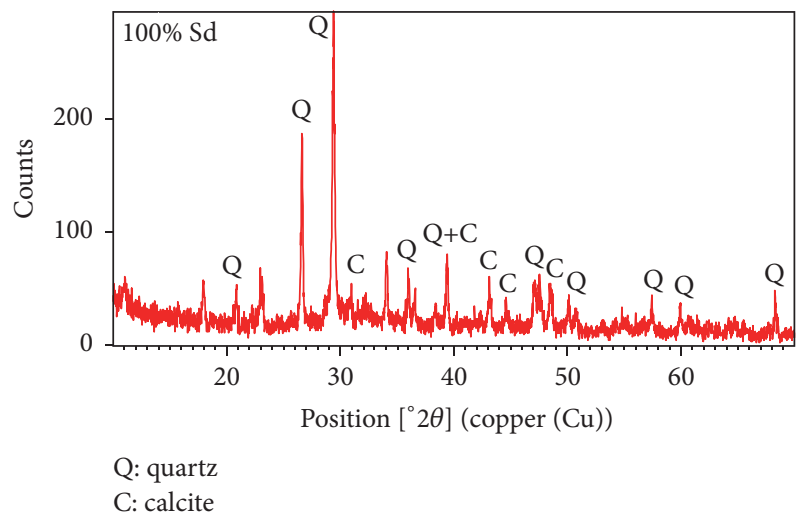

FIgURE 1: X-ray diffraction pattern for sand dune ( $\mathrm{K}_{a} \mathrm{Cu}$ radiation).

TABLE 2: Chemical composition of fine aggregates (crushed sand and dune sand) used (\%, by weight).

\begin{tabular}{lcc}
\hline Compounds & \multicolumn{2}{c}{ (\%, by weight) } \\
\hline Lime & 51.43 & SD \\
Silica & 03.31 & 2.94 \\
Alumina & 01.17 & 88.25 \\
Iron oxide & 01.09 & 00.71 \\
Potassium oxide & 00.09 & 00.96 \\
Sodium oxide & 00.01 & 00.30 \\
Sulfate & 00.55 & 00.01 \\
Magnesia & 00.91 & 00.08 \\
\hline
\end{tabular}

(iii) Binary Sand Mixtures. The binary sand mixtures aggregates used in this study were SD (dune sand) and CS (crushed sand). Four series of binary fine aggregate mixtures were 
TABLE 3: Physical characteristics of the mixed fine aggregates (crushed and dune sand).

\begin{tabular}{lcccccc}
\hline Sands & $\mathrm{App}\left(\mathrm{g} / \mathrm{cm}^{3}\right)$ & $\mathrm{Ab}\left(\mathrm{g} / \mathrm{cm}^{3}\right)$ & $M_{f}$ & $C(\%)$ & $P(\%)$ & $E(\%)$ \\
\hline $\mathrm{CS}$ & 1.95 & 2.70 & 3.29 & 72.23 & 27.77 & 38.45 \\
$1 / 3 \mathrm{SD}+2 / 3 \mathrm{CS}$ & 2.02 & 2.64 & 2.63 & 76.5 & 23.48 & 30.68 \\
$2 / 3 \mathrm{SD}+1 / 3 \mathrm{CS}$ & 2 & 2.63 & 2.94 & 75.05 & 23.95 & 31.49 \\
$\mathrm{SD}$ & 1.9 & 2.65 & 1.71 & 71.7 & 28.3 & 39.47
\end{tabular}

App: apparent density, Ab: absolute density $\left(\mathrm{g} / \mathrm{cm}^{3}\right), M_{f}$ : fineness modulus, $C$ : compactness (\%), $P$ : porosity (\%), and $E$ : void ratio (\%).

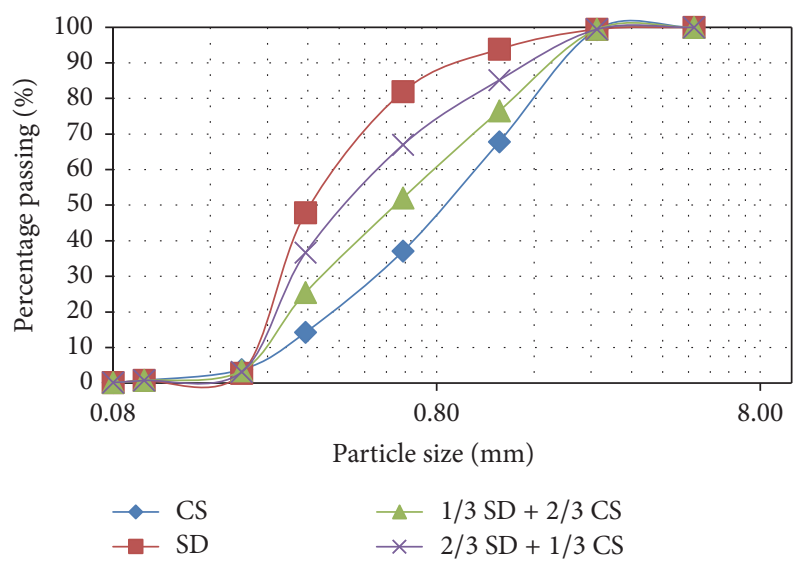

Figure 2: Particle size distribution of the sand studied.

prepared. The characteristics of binary sand mixtures are given in Table 5 and designated as HPC (SD) [0\% CS + $100 \% \mathrm{SD}], \mathrm{HPC}(\mathrm{CS})[100 \% \mathrm{CS}+0 \% \mathrm{SD}]$, HPC (1/3 SD) $[1 / 3 \mathrm{SD}+2 / 3 \mathrm{CS}]$, and HPC (2/3 SD) [2/3 SD + 1/3 CS]. The granulometric composition is an important indicator of the physical properties and structure of sand used in this study. The sieve analysis was obtained according to European standard NF EN 933-1 [23]. Their physical properties and chemical compositions are summarized in Tables 2 and 3.

Figure 2 shows the particle size distribution of the sand used. The particle size distribution of the natural aggregate (siliceous dune sand) and quarry waste fine aggregate (calcareous crushed sand) used was determined using dry sieve analysis method.

Porosity was calculated from the absolute density and bulk density values using the formula:

$$
P(\%)=\left(1-\frac{\rho}{\gamma}\right) \cdot 100,
$$

where $P$ is the porosity as the content of pores and voids in the specimens (wt.\%), $\gamma$ is the absolute density $\left(\mathrm{g} / \mathrm{cm}^{3}\right)$, and $\rho$ is the bulk gravity $\left(\mathrm{g} / \mathrm{cm}^{3}\right)$.

The method to combine natural and crushed sand improves the physical properties of prepared fine aggregate mix.

To improve the porosity of the binary mixture (crushed and dune sand) and correct the variation of the granulometric composition (particle sizes) we have to use $1 / 3$ and $2 / 3$ of crushed sand blend.

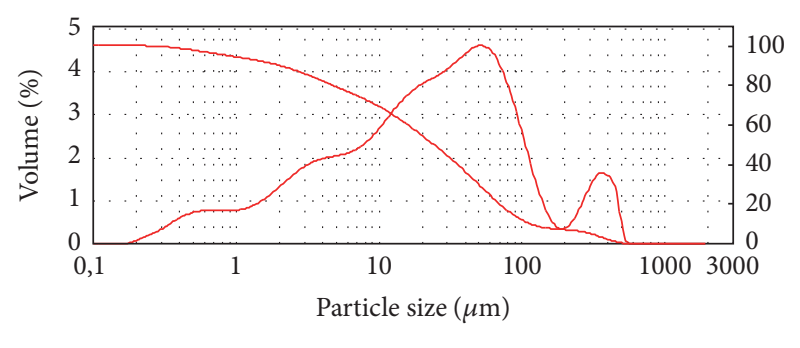

_ Slag

FIgUre 3: Particle size distribution of slag.

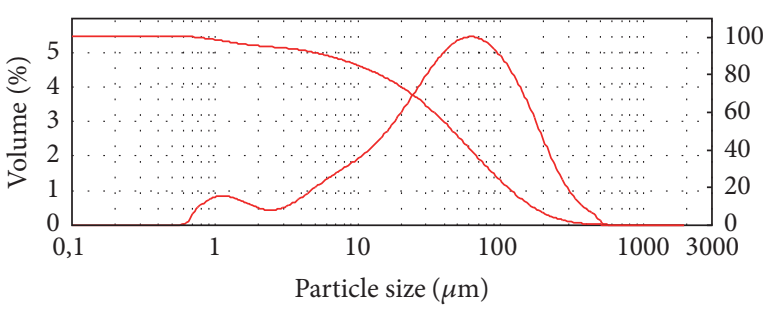

$-\mathrm{SF}$

FIgURE 4: Particle size distribution of silica fume.

(iv) Fines Added

(i) Fillers of granulated slag are obtained by milling the blast furnace slag of El-Hajar to a specific surface area of $5000 \mathrm{~cm}^{2} / \mathrm{g}$. This surface is larger than the specific surface of cement. The slag of El-Hadjar has the advantage of being rather acid (the $\mathrm{CaO} / \mathrm{SiO}_{2}$ report/ratio varies within the limits of 0.95 to 1.04 ); it is relatively stable.

(ii) Second filler is a silica fume (HP MEDAPLAST) of GRANITEX. Its specific surface area $>15 \mathrm{~m}^{2} / \mathrm{g}$. Chemical composition of cement and fillers used in this study is given in Table 1 . The particle size distributions of slag and silica fume are presented in Figures 3 and 4 .

(v) The Adjuvant. The adjuvant used is a superplasticizer high water reducing (Medaplast SP40). It is a solution of $\mathrm{pH}=$ 8.2 and a density of 1.22 , with $40 \%$ of solids. Its normal use scale is fixed by the manufacturer's recommendation which is between 0.6 and $2.5 \%$ of the cement weight. The percentage of the chemical admixture used was $1.5 \%$ by cement's weight for all mixes.

\section{Formulation of HPC}

3.1. Parameters of Formulation. The concrete formulation tested (mix design (Table 4)) is performed by formulating's method HPC of the Sherbrooke University, which allows the formulation of HPC without air entrained in accordance with standard ACI 211-1 [22]. The volume ratio of sans to aggregates $\left(V_{s} / V_{\text {gr }}\right)$ is equal to 0.67 , the cement is in the range 
TABLE 4: Mixing procedure of HPC.

\begin{tabular}{|c|c|}
\hline Time, sec. & Mixing procedure \\
\hline 60 & $\begin{array}{c}\text { Homogenization of aggregates, silica fume, } \\
\text { cement, and slag }\end{array}$ \\
\hline 30 & $\begin{array}{c}\text { Addition } 100 \% \text { of water and a third of the } \\
\text { volume superplasticizer }\end{array}$ \\
\hline 180 & Homogenization \\
\hline 30 & Addition of the remaining superplasticizer \\
\hline 60 & Homogenization \\
\hline
\end{tabular}

TABLE 5: Nomenclature of formulated HPC.

\begin{tabular}{lc}
\hline Concrete & Denomination \\
\hline $\begin{array}{l}\text { Concrete with sand dune, fillers (granulated slag, } \\
\text { silica fume) }[100 \% \mathrm{SD}]\end{array}$ & HPC (SD) \\
$\begin{array}{l}\text { Concrete with crushed sand, fillers (granulated } \\
\text { slag, silica fume) }[100 \% \mathrm{CS}]\end{array}$ & $\mathrm{HPC}(\mathrm{CS})$ \\
$\begin{array}{l}\text { Concrete with a mixture of sand (dune, crushed } \\
\text { sand), the weight ratio: SD/CS }=1 / 3 \text { or }[1 / 3 \mathrm{SD}\end{array}$ & $\mathrm{HPC}(1 / 3 \mathrm{SD})$ \\
$+2 / 3$ CS $].$ Fillers (granulated slag, silica fume). & \\
$\begin{array}{l}\text { Concrete with a mixture of sand (dune, crushed } \\
\text { sand), the weight ratio: SD/CS }=2 / 3 \text { or }[2 / 3 \mathrm{SD}+\end{array}$ & $\mathrm{HPC}(2 / 3 \mathrm{SD})$ \\
$1 / 3 \mathrm{CS}]$. Fillers (granulated slag, silica fume). &
\end{tabular}

of $C=420 \mathrm{~kg} / \mathrm{m}^{3}$, and the content of air is $1.5 \%$ (volume). In addition to the optimal mixture, other combinations were studied by replacing gradually CS by SD (1/3, $2 / 3$, and $100 \%)$. The dosage of superplasticizer was fixed at $1.5 \%$ relative to the binder content (cement + filler).

After testing convenience, the basic composition used for these types of concrete is as follows:

(i) Cement: $397 \mathrm{~kg} / \mathrm{m}^{3}$.

(ii) High furnace Slag: $46.7 \mathrm{Kg} / \mathrm{m}^{3}$.

(iii) Silica fume: $23.35 \mathrm{Kg} / \mathrm{m}^{3}$.

(iv) Gravels (3/8) and (8/16) mm: $1041.6 \mathrm{~kg} / \mathrm{m}^{3}$.

(v) Sand (0/5) mm: $701.48 \mathrm{~kg} / \mathrm{m}^{3}$.

(vi) Water $121.37: \mathrm{kg} / \mathrm{m}^{3}$.

(vii) Adjuvant: $1.5 \%$ by weight of cement for all mixes.

3.2. Formulation of HPC. Fresh concrete mixes were prepared in modified laboratory mixer (mixing procedure (Table 4)). Mixtures were prepared from dry aggregates. Cement and aggregates were dosed by weight and water and chemical admixtures were added by volume.

The concrete specimens are preserved in their mould in wet place $\left(20^{\circ} \mathrm{C}, 95 \% \mathrm{HR}\right)$ during 24 hours. Then they undergo immersed in the various conservation baths: potable water tap, solution of $\mathrm{MgSO}_{4}$ with mass concentration of $5 \%$ at $20^{\circ} \mathrm{C}$ until the fixed terms. The physical, mechanical characteristics of the concrete are compared. Nomenclatures of formulated concrete used in this study are given in Table 5 .

Cubic test specimens $(100 \times 100 \times 100) \mathrm{mm}^{3}$ were used for the determination of the compressive strength at 28,270 , and

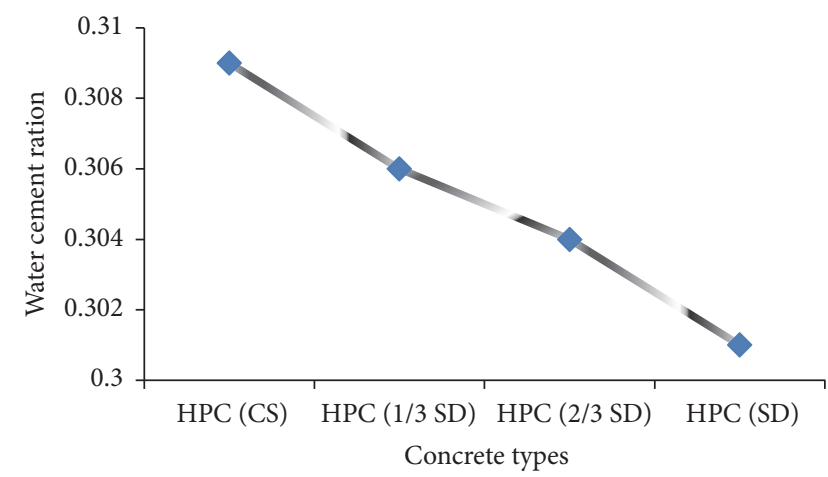

FIGURE 5: Variation of W/C for various percentages of crushed sand.

365 days according to NF EN 12390-4 [24]. The test pieces for testing of capillarity and water porosity are dried in a stove at a temperature of $100^{\circ} \mathrm{C}$ to constant weight and then returned to room temperature in a desiccator.

The Water Absorption by Capillarity. It was applied in sample cylindrical shape of concrete with $10 \mathrm{~cm}$ diameter and $12 \mathrm{~cm}$ high, placed in contact with a free water of $1 \mathrm{~cm}$ height maintained at a constant level.

The side faces are coated with a self-adhesive aluminum foil [25-27], which forces the water to pass a uniaxial tracking and prevents evaporation, by the same faces. The mass of water absorbed is determined by successive weighing of samples depending on $\sqrt{h}$ ( $h$ present hour); the only precaution to take is removing the film of water retained on the sample's underside before each weighing, using an absorbent paper.

The Protocol of Porosity. The protocol of porosity accessible to water conforms to the recommendations of AFREM [26] group. The open porosity allows us to appreciate the evolution of hydration and structuration of hydrated products; this is a key for identification of the most sustainable concrete [28].

The Slump Test. It is a method of testing the workability of the fresh concrete. Filling a standard metal slump cone by 3 layers of concrete, each layer would be thoroughly compacted with a steel rod. The last layer which fills the cone to the top would be trowelled flat. Then the cone is then removed and the height reduction (slump) of the concrete is measured. The slump test is used for evaluation of rheological behavior of a mixture [29]. The slump was fixed between 6 and $7 \mathrm{~cm}$ for all mixes in this study.

\section{Results and Discussion}

4.1. Effect of Crushed Sand on the Water Cement Ratio (Properties of Fresh Concrete). The results of water's variation cement ratio for various percentages of crushed sand of fresh concrete are presented in Figure 5.

The concrete made with binary sand (1/3 SD and $2 / 3$ $\mathrm{SD})$ presents a high water/cement in comparison with the concrete $(\mathrm{SD})$. The difference observed between the water/cement of various types of concrete tested depends on 


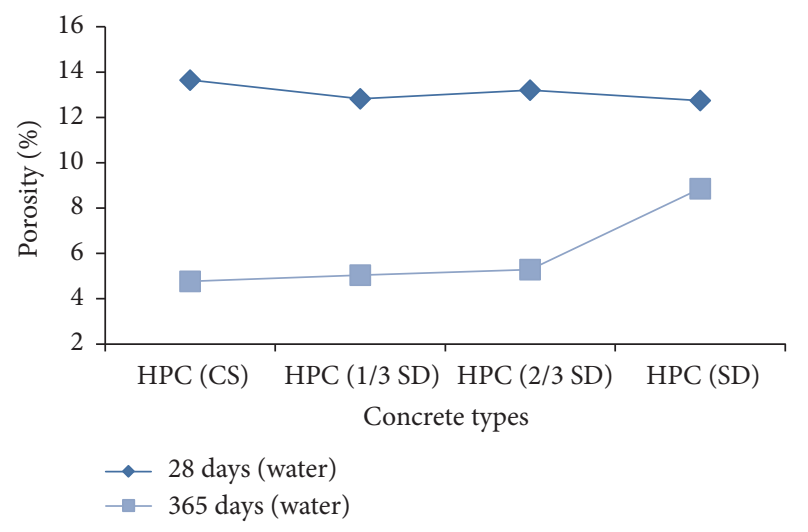

FIGURE 6: Variation of the porosity of various percentages of CS conservation in potable tap water.

the content of the crushed sand incorporated in the natural fine aggregate (difference of the density and the porosity between the different fines aggregates studied). The test results show that water/cement ratio and water absorption values of crushed sand concrete mixtures decreased with the increase in level of fine aggregate replacement by crushed sand.

Figure 5 shows that increasing the percentage of crushed sand for all concrete studied is generated by increasing in the mixing amount of water. This is due primarily to cohesion force between the particles of angular shape of the sand and the presence of fines that contain the crushed sand; it reaches 3\% for the concrete with CS. The present results obtained are in accordance with research work undertaken by Abdullahi [30]. On the other hand, the incorporation of water-reducing admixture (1.5\% of Medaplast SP40) allows a significant reduction of mixing water for all concrete despite the high percentages of crushed sand used. This reduction due to the role of chemical admixture allows deflocculating fine particles of cement, which allows an increase in the compactness and lubricates the solid surfaces by reducing friction stress between particles (mechanical effect).

\subsection{Physical Properties}

4.2.1. Effect of Crushed Sand on the Porosity. The results of porosity tests are shown in Figure 6. In the short term (28 days), the concrete made with binary sand (natural and manufactured fine aggregates) presents a low porosity (low improvement) in comparison with the concrete HPC (SD). This variance observed between the porosity of various concrete tested depends of the variation of the physical properties for each type of fines aggregates studied.

In the long term (365 days) the results show that the porosity of high performance concrete decreases with the same constituents. This is due to the difference of the density and the porosity between the different fine aggregates used (angular crushed, round dune sand, and fillers). In fact, the porosity (voids and pores) is influenced by the padding characteristics of the full mixture that includes fine aggregates, cement, and water [31].

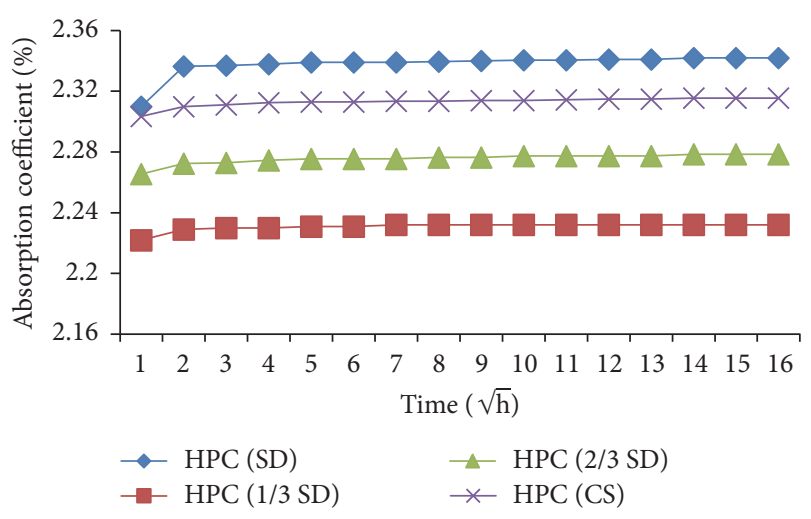

FIGURE 7: Absorption coefficients by capillarity of HPC.

According to Figure 6, we notice that the partial replacement of natural sand (SD) by manufactured sand (1/3 SD and $2 / 3$ of CS combined) results in a low decrease in porosity at 365 days, but at $100 \%$ of sand dune there is a significant increase in the porosity (for concrete HPC (SD) the increased of porosity ration is $8 \%$ ) due to a chemical phenomenon, not physical one.

On the other hand, the use of the water-reducing admixture (1.5\% of Medaplast SP40) decreases the void ratio, because the lubricate facilitates the rearrangement of particles and thus the concrete becomes less porous and more compact. The incorporation of sand dune with a crushed sand in HPC leads to increase in the compactness related to the increase of the rheological properties.

4.2.2. Effect of Crushed Sand on Water Absorption by Capillarity. The variations of water absorption by capillarity of concrete for various percentages of crushed sand are shown in Figure 7.

The results show that the water absorption of concrete increases with the content of sand dune substituted; this is due to the dissimilarity of the density and the porosity between the different fine aggregates used (angular crushed and round dune sand) [30].

In effect, the porosity is influenced by the packing characteristics of the entire mixture that includes fine aggregates, cement, and water. Also, the water absorption values of concrete made with binary sand mixtures are lower (2.2\%) than those of concrete with sand dune SD (2.34\%). The use of the chemical admixture (1.5\% of Medaplast HP 40) allows reducing the number of voids and pores existing in the concrete, which consequently becomes more compact, more resistant, and more water proof.

The water absorption is linearly relative to the total porosity of the concrete.

\subsection{Mechanical Properties}

4.3.1. Effect of Crushed Sand on the Mechanical Strengths. The results of the compressive strengths of the concrete with and without crushed fine aggregates at 28 days, 270 days, and 365 days are schemed in Figure 8. 


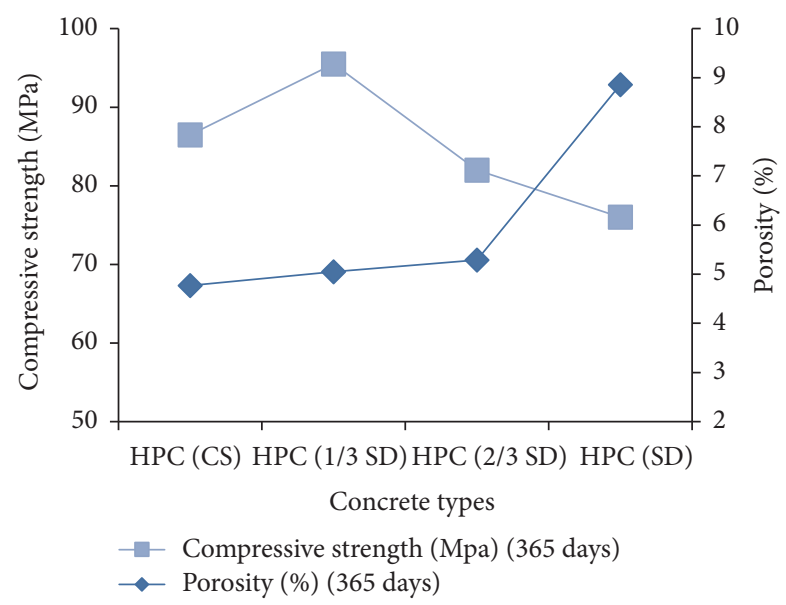

FIGURE 8: Evolution of mechanical strengths of HPC immersed in potable tap water according to the porosity.

The partial replacement of natural sand (SD) by crushed sand $(1 / 3,2 / 3$ of CS combined) results in increasing compressive strengths of the concrete HPC $(1 / 3 \mathrm{SD})$ and HPC $(2 / 3 \mathrm{SD})$ compared to the concrete HPC (SD). The use of manufacture sand increases the mechanical strength of the concrete, depending on the percentage of crushed sand used.

The results obtained ( 28 to 365 days) agree in a clear way that the incorporation of crushed sand (1/3,2/3 of CS) in the dune sand (SD) improves the compressive strength of the concrete tested based on binary mixtures.

This can explain the fact why nature and the grain-size distribution are the principal parameters which influence the increase in the mechanical comportment of the concrete tested. The strength gain of the concrete tested was superior for the concrete containing binary sand (1/3 SD) and (2/3 SD) for the compressive strength to that of the concrete (SD).

In conclusion, one determined that from $1 / 3$ up to $2 / 3$ of crushed sand we notice an improvement of the compressive strength of concrete. We notice that the use of the $2 / 3$ CS increases the mechanical strengths of the concrete of more than $25 \%$ at 365 days [15].

4.3.2. Effect of Porosity of Binary Sand on the Mechanical Strength. Figure 8 shows the rapport between porosity of binary sand and compressive strength of concrete studied.

It shows that increasing of porosity of crushed sand influences significantly the compressive strengths of concrete tested but such reduction was found to be very limited, particularly for concrete prepared with binary sand. In general, increasing porosity of binary sand results in decreasing the compressive strength of concrete. Porosity and texture of sand have an important effect on compressive strength and durability of hardened concrete. Porosity of binary sand also affects the mechanical strength and water absorption of concrete, and it will affect the performance of both freshly mixed and hardened concrete.

From the result of porosity of binary sand, it can be concluded that the sample incorporation with different percentage crushed sand replacement has lower percentage of

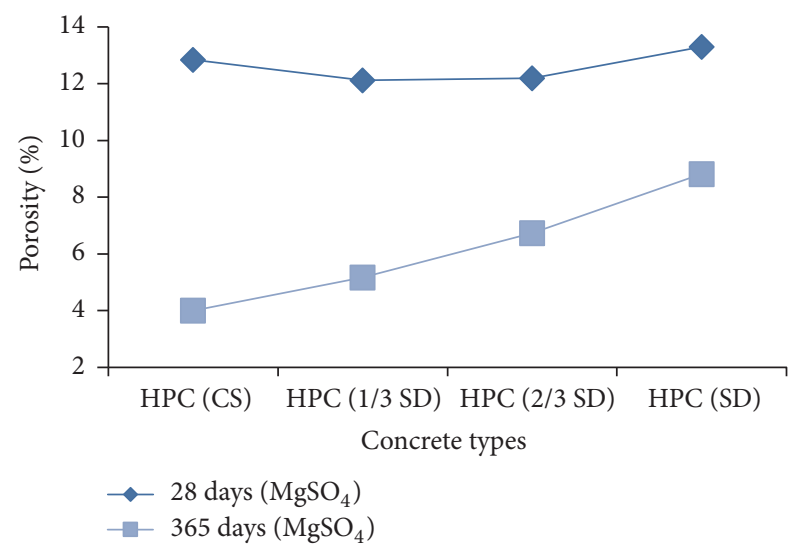

FIGURE 9: Variation of the porosity of various percentages of crushed sand conservation in solution $\mathrm{MgSO}_{4}$.

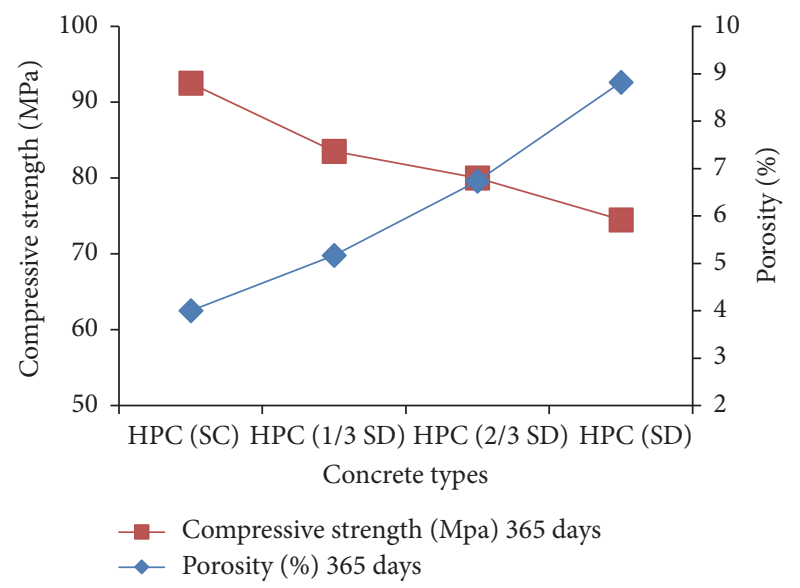

FIGURE 10: Evolution of mechanical strengths of HPC immersed in the solution $\left(\mathrm{MgSO}_{4}\right)$ depending on the porosity.

porosity of the binary mixtures HPC (1/3 SD) and HPC (2/3 $\mathrm{SD})$ compared with the mixture (HPC SD). The porosity of binary sand decreased with an increase in the replacement of $1 / 3 \mathrm{CS}$ and $2 / 3 \mathrm{CS}$ and of crushed sand. This is due to the lower volume of voids inside the binary sand $[32,33]$.

\subsubsection{Mechanical Strength to Chemical Attack}

(1) Effect of Porosity of Binary Sand on the Mechanical Strength. Figures 9 and 10 show the rapport between porosity of binary sand and compressive strength of concrete conserved in solution $\mathrm{MgSO}_{4}$. Figure 12 shows that the increase of porosity of binary sand influences considerably the mechanical strengths of concrete immersed in the solution $\left(\mathrm{MgSO}_{4}\right)$. In general, decreasing crushed sand results in a decrease in the compressive strengths of concrete, but such reduction was found to be very limited, particularly for concrete prepared with binary sand. In fact, the effects of shape and texture of fine aggregate are much more important than the effects of concrete characteristics. Similar results were found when using potable tap water. 


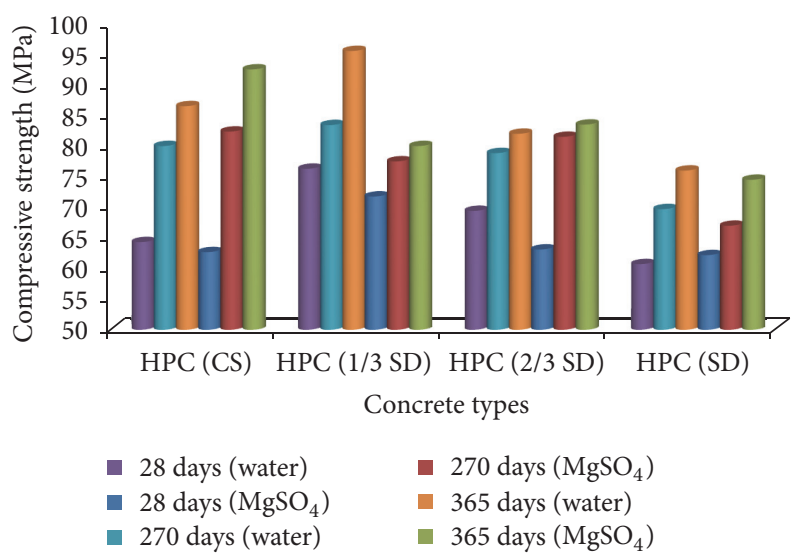

FIGURE 11: Compressive strength of HPC.

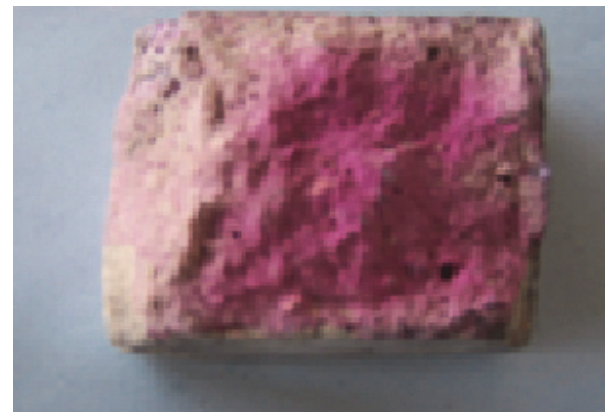

FIGURE 12: Evolution of $\mathrm{pH}$ of HPC.

Figure 11 shows the variation of the compressive strength in function of time of concrete immersed in the solution of sulfate magnesium $\left(\mathrm{MgSO}_{4}\right)$ for $(28,270$, and 365 days). From the results obtained it can be seen that, after a period of 365 days, HPC (1/3 SD) and HPC (CS) have presented the best mechanical strengths in aggressive media $\left(\mathrm{MgSO}_{4}\right)$. Also, the combination of dune sand and crushed sand causes an increase in the compressive strength, which confirms the results obtained previously in the study of porosity (Figures 8 and 10).

After the compression test, to illustrate the extent of dissolution of the portlandite by sulfatic medium we applied the phenolphthalein to $1 \%$ in ethanol on the internal parts of the half-pieces of concrete conserved in media aggressive. The results presented in Figure 12 show no decrease in $\mathrm{pH}$, so there is not any loss or alteration of concrete material.

This study has allowed us to highlight the effect of sulfates and chlorides on HPC.

To explain the results, we can recall the mechanism of transport of aggressive ions and also the main factors affecting the durability of concrete:

(i) Chlorides can penetrate the concrete surface by two types of transport mechanisms:

(a) Capillary sorptivity: the chlorides are dissolved first, "driven" into the pores together with the water absorbed (in cycles of wetting drying for example).

(b) Diffusion in the liquid phase: with addition of the absorption zone, chloride penetration is by diffusion. A portion of the ions can be "trapped" in the cement paste. There are two mechanisms to capture ions:

(A) Adsorption on the inner surfaces of the pores or hydrates.

(B) Interactions with chemicals to form aluminates of calcium chloroaluminates (Friedel $\mathrm{C}_{3} \mathrm{~A} \cdot \mathrm{CaCl}_{2} \cdot 10 \mathrm{H}_{2} \mathrm{O}$ salt) which are relatively little damaging [34].

(ii) The presence of fillers has a great influence on the resistance obtained by the control concrete.

Indeed, silica fume and slags decrease very significantly the diffusion coefficient of chloride ions. Replacement of $10 \%$ of cement by silica fume can reduce the diffusion coefficient by a factor of 5 to 10, particularly if the W/binder ratio is relatively high [35].

The second influencing factor is the water/binder ratio, which, in our case, is 0.30 , very low. This report shows great importance, indeed:

(I) The diffusion coefficient increases with the increase of $\mathrm{W} /$ Binder.

Long ripening (one year) can further split the capillary pore network. We can significantly reduce the diffusion coefficient in maintaining longer favorable curing conditions (effect of water/binder ratio and the ripening on the diffusion coefficient of chlorine ions) [19-36].

(iii) The replacement of dune sand by crushed sand in concrete specimens has the effect of improving the mechanical resistance in aggressive environments

(2) Internal Structure. XRD patterns, ATG, and ATD of concrete immersed in solution $\mathrm{MgSO}_{4}$ for 365 days are shown in Figures 13 and 14.

The analysis by X-ray diffraction is carried out in the physics Laboratory University of M'sila by an X-ray diffractometer (X'Pert) coupled to a computer system.

The essential purpose of this analysis is to identify the different phase's crystal present in a sample. The analysis of the spectrum of Figure 13 is used to report the following findings:

(i) The presence of quartz $\mathrm{SiO}_{2}$, confirming the presence of sand.

(ii) The presence of calcite $\mathrm{CaCO}_{3}$, obtained by carbonation of lime.

(iii) The presence of traces of portlandite $\mathrm{Ca}(\mathrm{OH})_{2}$ 


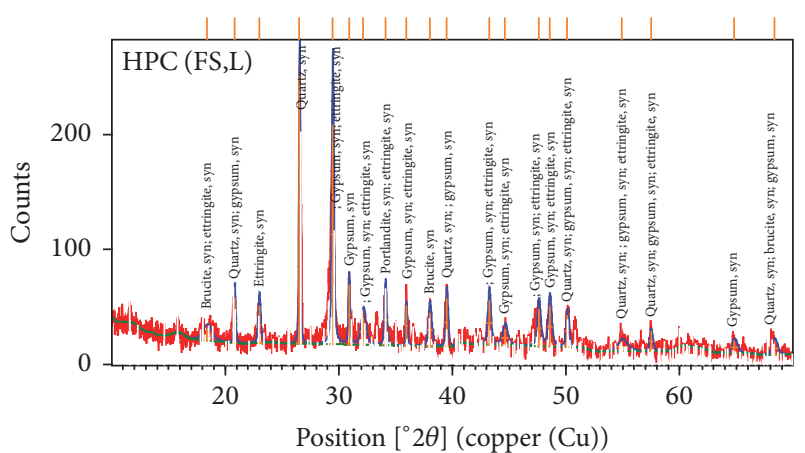

FIGURE 13: XRD patterns powder of concrete with binary sand.

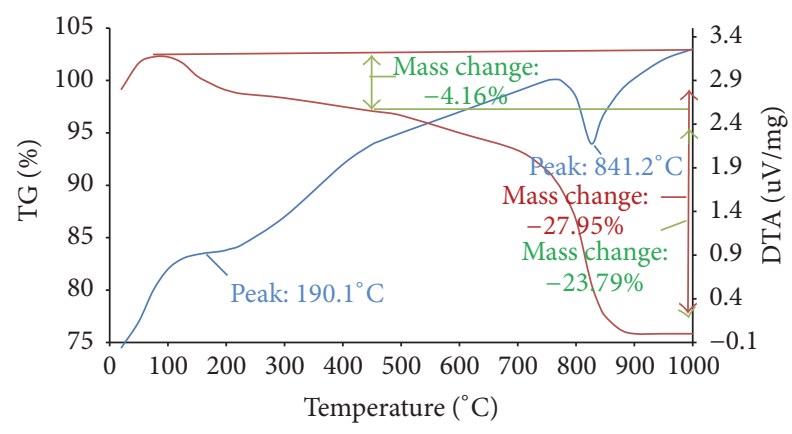

FIGURE 14: ATG and ATD powder of concrete with binary sand.

The X-ray analysis, of different concrete after 365 days of immersion in the solution of $\mathrm{MgSO}_{4}$, shows the appearance of two new phases, which are

(i) ettringite secondary $3 \mathrm{CaO} \mathrm{Al} \mathrm{O}_{3} \mathrm{CaSO}_{4} 32 \mathrm{H}_{2} \mathrm{O}_{3}$;

(ii) the hydrated gypsum $\mathrm{CaSO}_{4} 2 \mathrm{H}_{2} \mathrm{O}$.

\section{Conclusions}

The main objective of this experimental work is to valorize local materials and quarry wastes by using them in construction. It objects at the study of the effect of use of crushed sand as partial replacement of dune sand in various percentages $(1,1 / 3$, and $2 / 3)$ on the physicomechanical properties of concrete made with binary natural fine aggregates (SD and CS). Starting from the test results, the following can be concluded:

(i) Adding crushed sand improves the physical properties of binary sand (grading, low porosity, high compactness, etc.).

(ii) The results obtained agree in a clear way that the combination of crushed sand $(1 / 3$ and $2 / 3)$ in the dune sand improves the mechanical strength compressive of the concrete tested to base of the binary mixtures (1/3 CS, 2/3 CS).

(iii) A percentage of $1 / 3 \mathrm{SD}$ provides compressive strength in sulfated medium equivalent to those obtained in the tap water. However, more than $30 \%$ substitution causes a decrease resistance. (iv) Indeed, the sand dune confers a high porosity to concrete (Figures 8 and 10), which negatively affects the mechanical strength.

(v) The results of physical and mechanical tests show no significant alteration of concrete kept in sulfated water even after 1-year ripening. Also, the phenolphthalein essay shows no decrease in $\mathrm{pH}$, so no alteration (loss of material) of concrete.

(vi) The pozzolanic reaction of the silica fume and slag with the released lime tends to produce $\mathrm{CSH}$, so that the amount of binder is increased. Twice the effects increase the compressive strength and give the dense structure.

(vii) The workability of high performance concrete is influenced positively by the replacement the SD by CS.

(viii) In general, it can be concluded that the incorporation of addition such as CS combined with SD could be beneficial to produce alternative binders to formulate a high performance concrete (HPC).

\section{Competing Interests}

The authors declare that they have no competing interests.

\section{References}

[1] S. P. S. Rajput and M. S. Chauhan, "Suitability of crushed stone dust as fine aggregate in mortars," International Journal of Emerging Technology and Advanced Engineering, vol. 4, pp. 87-89, 2014.

[2] B. Menadi, S. Kenai, J. Khatib, and A. Aït-Mokhtar, "Strength and durability of concrete incorporating crushed limestone sand," Construction and Building Materials, vol. 23, no. 2, pp. 625-633, 2009.

[3] M. Bederina, Z. Makhloufi, A. Bounoua, T. Bouziani, and M. Quéneudec, "Effect of partial and total replacement of siliceous river sand with limestone crushed sand on the durability of mortars exposed to chemical solutions," Construction and Building Materials, vol. 47, pp. 146-158, 2013.

[4] T. Celik and K. Marar, "Effects of crushed stone dust on some properties of concrete," Cement and Concrete Research, vol. 26, no. 7, pp. 1121-1130, 1996.

[5] M. Yajurved Reddy, D. V. Swetha, and S. K. Dhani, "Study on properties of concrete with manufactured sand as replacement to natural sand," International Journal of Civil Engineering and Technology, vol. 6, no. 8, Article ID IJCIET_06_08_004, pp. 2942, 2015.

[6] B. P. Hudson, "Manufactured sand for concrete," The Indian Concrete Journal, vol. 71, no. 5, pp. 237-240, 1997.

[7] S. Ahmad and S. Mahmood, "Effects of crushed and natural sand on the properties of fresh and hardened concrete," in Proceedings of the 33rd Conference on Our World in Concrete \& Structures, Singapore, August 2008.

[8] R. Ilangovan, K. Nagamani, and K. Kumarasamy, "Studies on strength and behaviour of concrete by using crushed rock dust as fine aggregate," Civil Engineering and Construction Review, pp. 924-932, 2006. 
[9] L. Baali, A. Naceri, and R. Mehamed, "Mechanical response of mortar made with natural and artificial fine aggregates," Asian Journal of Civil Engineering (Building and Housing), vol. 9, pp. 85-92, 2007.

[10] C. Narasimha, B. T. Patil, and S. H. Sanni, "Performance of concrete with quarry dust as fine aggregate-An Experimental Study," Civil Engineering and Review, vol. 12, pp. 19-24, 1999.

[11] A. K. Sahu, K. Sunil, and A. K. Sachan, "Crushed stone waste as fine aggregate for concrete," The Indian Concrete Journal, vol. 77, no. 1, pp. 845-848, 2003.

[12] Z. Makhloufi, M. Bederina, M. Bouhicha, and E.-H. Kadri, "Effect of mineral admixtures on resistance to sulfuric acid solution of mortars with quaternary binders," Physics Procedia, vol. 55, pp. 329-335, 2014.

[13] R. Vinayak, "Supekar, properties of concrete by replacement of natural sand with artificial sand," International Journal of Engineering Research \& Technology, vol. 1, no. 7, 2012.

[14] A. Priyanka, "Effect of replacement of natural sand by manufactured sand on the properties of cement mortar," International Journal of Civil and Structural Engineering, vol. 3, no. 3, article 621, 2013.

[15] A. R'mili and M. Ben Ouezdou, "Valorization of the crushed sand and of the desert sand in the composition of the selfcompacting concrete," in Proceedings of the 2nd International Seminar INVACO-Innovation \& Valorization in Civil Engineering \& Construction Materials, 2012.

[16] 2012, https://www.metakaolin.info.

[17] M. Alexander and A. Bertron, "Performance of cement-based materials in aggressive aqueous environments State-of-the-Art Report," RILEM TC 211-PAE, vol. 10, 2013.

[18] G. Escadeills, "Les éco-matériaux dans la construction: enjeux et perspectives. Septième édition des Journées scientifiques du Regroupement francophone pour la recherche et la formation sur le béton (RF) 2B," 2006.

[19] R. K. Dhir and E. A. Byars, "PFA concrete: chloride diffusion rates," Magazine of Concrete Research, vol. 45, no. 162, pp. 1-9, 1993.

[20] R. Gao, Q. Li, and S. Zhao, "Concrete deterioration mechanisms under combined sulfate attack and flexural loading," Journal of Materials in Civil Engineering, vol. 25, no. 1, pp. 39-44, 2013.

[21] M. R. Khelifa, Effet de l'attaque sulfatique externe sur la durabilité des bétons autoplacants [Ph.D. thesis], Centre de Recherche sur la Matiére Divisée Oreléans/Laboratoire de Genie Civil Costantine, 2009.

[22] P. C. Aïtcin, Bétons Haute Performance, édition Eyrolles, 2001.

[23] "Essais pour déterminer les caractéristiques géométriques des granulats-partie 1: détermination de la granularité-analyse granulométrique par tamisage," NF EN 933-1, 2006.

[24] NF EN 12390-4 EN 12390-5, "Essai pour béton durci, Partie 5: Résistance à la flexion sur éprouvettes," 2009.

[25] G. Arliguie and H. Hormain, "Recommandation AFREM. Bétons. Déterminatio n de la masse volumique apparente et de la porosité accessible à l'eau," Presses de L'École National des Ponts et Chaussées, 2007.

[26] T. Chaussadent and G. Arliguie, "AFREM test procedures concerning chlorides in concrete: extraction and titration methods," Materials and Structures, vol. 32, no. 3, pp. 230-234, 1999.

[27] http://doc.lerm.fr/lerm-infos-n-19-le-soufre/.

[28] A. Bessa, Etude de la contribution des additions minérales aux propriétés physiques, mécaniques et de durabilité des mortiers [Ph.D. thesis], Université de Cergy, Pontoise, France, 2004.
[29] "Essai pour béton durci-partie 5: résistance à la flexion sur éprouvettes," NF EN 12390-4 EN 12390-5, 2009.

[30] M. Abdullahi, "Effect of aggregate type on compressive strength of concrete," International Journal of Civil and Structural Engineering, vol. 2, no. 3, pp. 791-800, 2012.

[31] S. A. Abo-El-Enein, H. A. El-Sayed, A. H. Ali, Y. T. Mohammed, H. M. Khater, and A. S. Ouda, "Physico-mechanical properties of high performance concrete using different aggregates in presence of silica fume," HBRC Journal, vol. 10, no. 1, pp. 43-48, 2014.

[32] P. A. Jadhav and D. K. Kulkarni, "Effect of replacement of natural sand by manufactured sand on the properties of cement mortar," International Journal of Civil and Structural Engineering, vol. 3, pp. 621-628, 2013.

[33] O. M. Omar, G. D. Abd Elhameed, M. A. Sherif, and H. A. Mohamadien, "Influence of limestone waste as partial replacement material for sand and marble powder in concrete properties," HBRC Journal, vol. 8, no. 3, pp. 193-203, 2012.

[34] M. R. Jones, M. J. McCarthy, and R. K. Dhir, "Chloride resistant concrete," in Proceedings of the International Conference on Economic and Durable Construction through Excellence 2000, vol. 2, pp. 1429-1444, E \& FN Spon, Dundee, UK, September 1993.

[35] N. Tebbal, Z. Rahmouni, and M. Belouadah, "Influence d'un ajout sur le comportement mécanique des bétons à haute performance soumis à des températures élevées," 30ème Rencontres AUGC-IBPSA Chambéry, Savoie, France, 6 au 8 juin 2012.

[36] N. Tebbal, Z. Rahmouni, and L. Belagraa, "Combined effect of granulated slag and silica fume on the characteristics of high performance concrete," International Review of Civil Engineering, vol. 7, no. 2, 2016. 


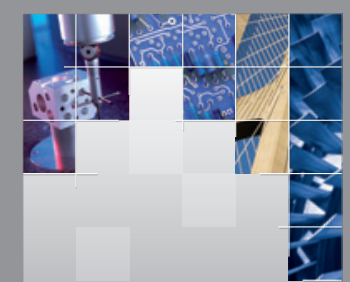

\section{Enfincering}
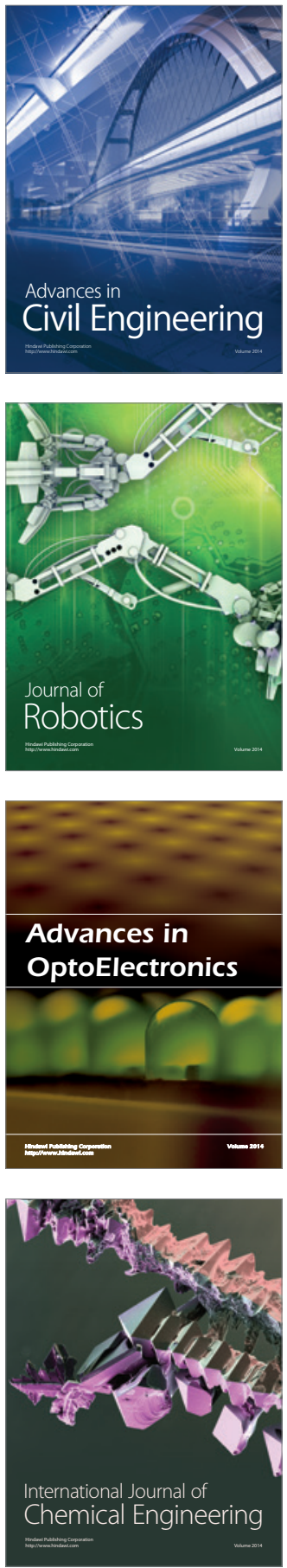

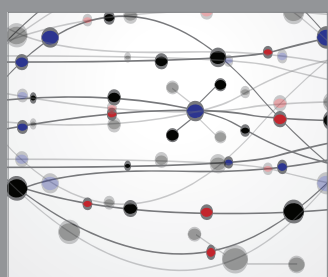

The Scientific World Journal

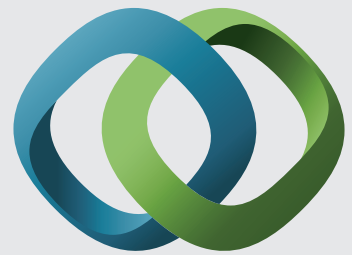

\section{Hindawi}

Submit your manuscripts at

http://www.hindawi.com
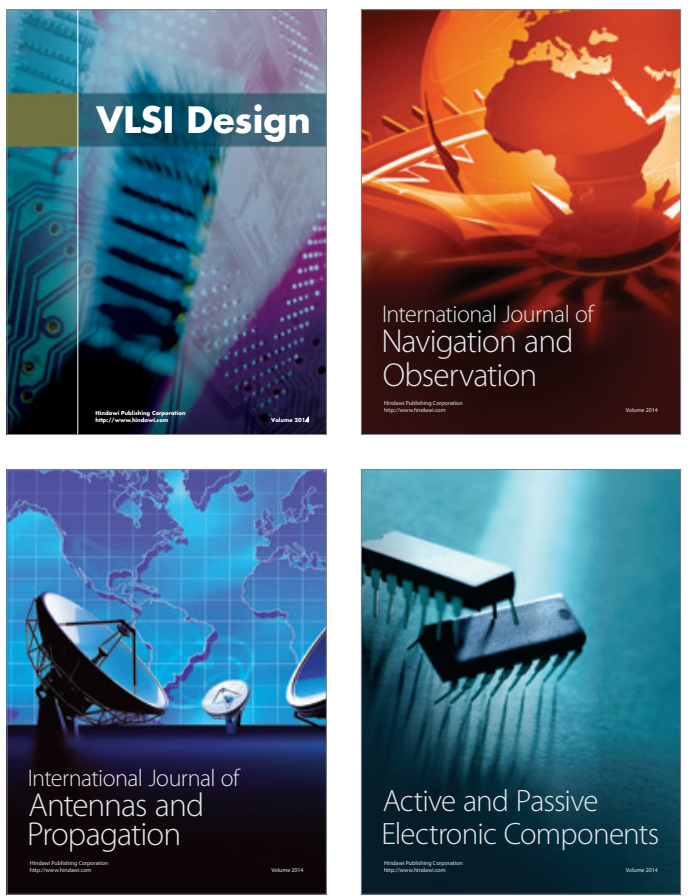
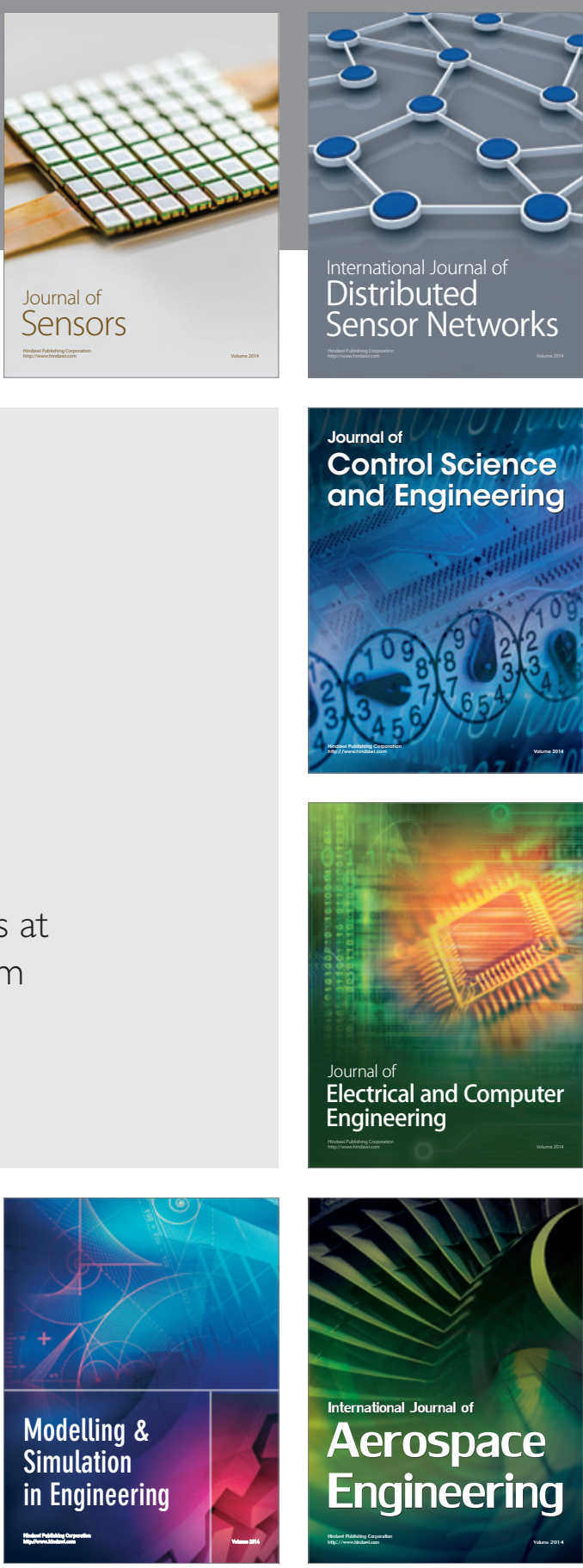

International Journal of

Distributed

Sensor Networks

Journal of

Control Science

and Engineering
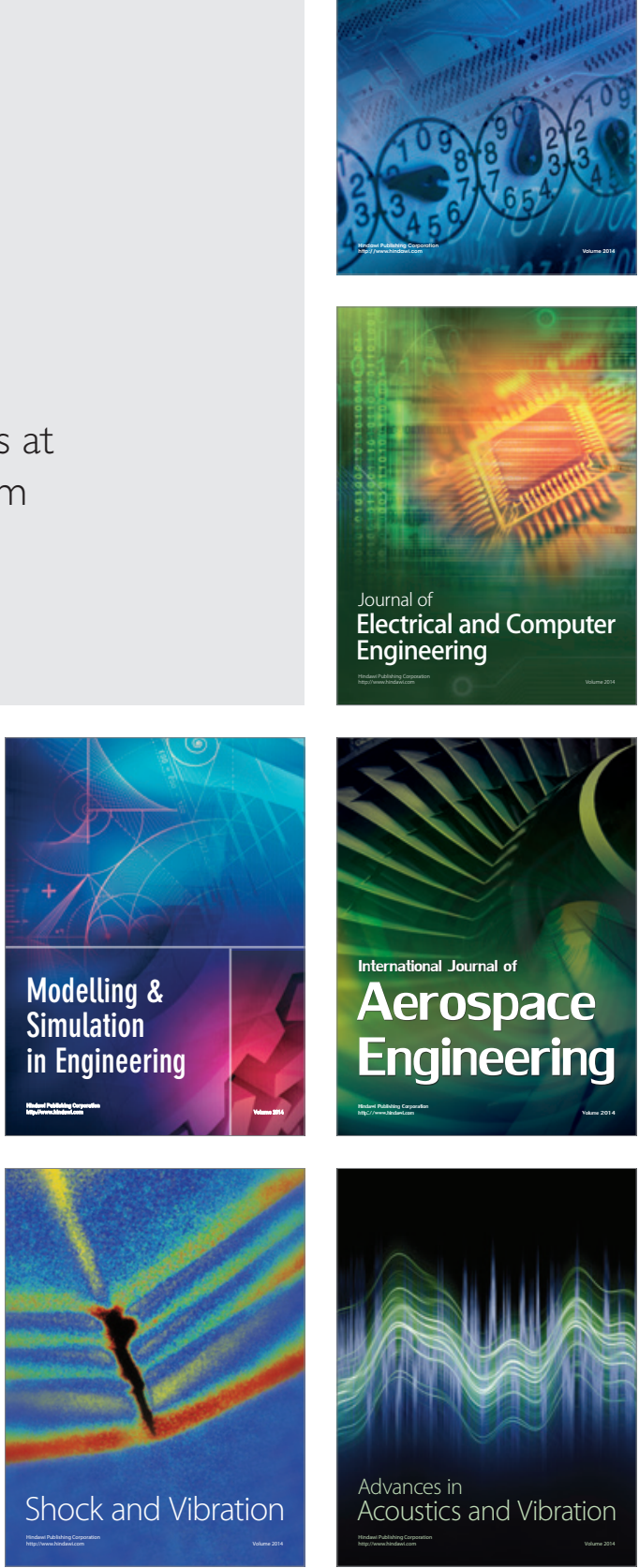